\title{
Regenerative Medicine and Stem Cells: Prometheus Revisited
}

\author{
Demosthenes Bouros ${ }^{a}$ Geoff Laurent ${ }^{b, c}$ \\ ${ }^{a}$ Department of Pneumonology, Medical School, Democritus University of Thrace, Alexandroupolis, Greece; \\ ${ }^{b}$ Centre for Cell Therapy and Regenerative Medicine, University of Western Australia, Perth, W.A.; ${ }^{c}$ Centre for \\ Respiratory Research, University College London, London, UK
}

The concept of tissue regeneration is not new and can be traced back to Greek mythology. Prometheus stole fire from the Olympian gods for human use in order to advance civilization. Zeus sentenced him to eternal torment for his disobedience. The immortal Prometheus was bound to a rock where each day an eagle was sent to feed on his liver, only to have it grow back to be eaten again the next day (... a long-winged eagle, which used to eat his immortal liver; but by night the liver grew as much again everyway as the long-winged bird devoured in the whole day) [1].

Improved health care and increased life expectancy have resulted in a dramatic increase in the prevalence of diseases associated with aging in developed countries. Many of these diseases arise from the loss or dysfunction of specific cell types, with fibrosis as a common feature. The US government estimates that $45 \%$ of deaths in the USA can be attributed to fibrotic disorders [2]. Thus, there is a desperate need for new and innovative therapies for a number of chronic lung diseases, including COPD, interstitial lung diseases (especially idiopathic pulmonary fibrosis), cystic fibrosis, and pulmonary hypertension [3].

Regenerative medicine offers a transformational approach to therapy pairing the power of stem cells and the body's own regenerative capabilities to restore function to damaged tissues and organs. In other words, regenerative medicine is the 'process of replacing or regenerating human cells, tissues or organs to restore or establish normal function' $[4,5]$. It includes a group of biomedical approaches to clinical therapies that may involve the use of stem cells. Examples include: the injection of stem cells or progenitor cells (cell therapies), the induction of regeneration by biologically active molecules administered alone or as products of injected cells (immunomodulation therapy), and transplantation of in vitro grown organs and tissues (tissue engineering) [6,7].

Despite substantial developments in our knowledge and understanding of stem cell biology and regenerative medicine, the field is in its infancy. As always, the translation of new concepts to better treatments is challenging and thus far major therapeutic breakthroughs have been rare. Alternative treatment strategies are urgently needed due to donor organ shortage that costs many lives every year and results in lifelong immunosuppression $[8,9]$. Pulmonary and critical care medicine has lagged behind other fields, like hematology and cardiology, including stem cells and regenerative medicine. [7]. However, cellbased regenerative therapies for lung diseases offer great promise, with preclinical studies suggesting that this approach is feasible and may provide a new therapeutic approach [10-15].

\section{KARGER}

Fax +4161306 1234

E-Mail karger@karger.ch

www.karger.com (c) 2012 S. Karger AG, Basel

0025-7931/13/0851-0001\$38.00/0

Accessible online at:

www.karger.com/res
Prof. Demosthenes Bouros, MD, PhD, FCCP

Head, Department Pneumonology

Medical School, Democritus University of Thrace

GR-68100 Alexandroupolis (Greece)

E-Mail bouros@med.duth.gr 
In this thematic review series on regenerative medicine and stem cells, we aim to introduce the promise and challenges of regenerative medicine in the context of lung diseases. The series begins with the introduction to stem cells and regenerative medicine; the next chapter is devoted to the biology of stem cells, highlighting recent developments and current challenges to better understand the biology of these cells and how they modulate inflammatory processes and promote tissue repair. Mesenchymal stem cells have been shown to be effective in a range of murine models of respiratory disease and are currently being evaluated in several clinical trials for a variety of chronic and acute lung diseases. Also, in this series separate articles review the clinical application of stem cells to common chronic and acute pulmonary diseases. These include idiopathic pulmonary fibrosis, COPD, cystic fibrosis, and pulmonary artery hypertension and acute lung injury. Lastly, lung cancer stem cell treatment is of particular interest and is included in the series.

In summary, stem cell biology and regenerative medicine offers transformational approaches to treat lung diseases that have thus far proved intractable to current therapeutic approaches. The challenge for the future is to illuminate areas in which the science is poorly understood and explore important practical challenges related to cell therapy including the best source, expansion methodology, route, and timing of administration of these cells. The next steps need commitment from all of us, combing the talents of pulmonary physicians and scientists from diverse disciplines.

\section{References}

1 Theogony; in Hesiod: Homeric Hymns, Epic Cycle, Homerica. Translated by EvelynWhite. H.G. Loeb Classical Library volume 57. London, Heinemann, 1914.

2 Wynn TA: Fibrotic disease and the T(H)1/ $\mathrm{T}(\mathrm{H}) 2$ paradigm. Nat Rev Immunol 2004;4: 583-594.

- 3 Pérez López S, Otero Hernández J: Advances in stem cell therapy. Adv Exp Med Biol 2012; 741:290-313.

4 Mason C, Dunnill P: A brief definition of regenerative medicine. Regen Med 2008;3:1-5.

5 Regenerative medicine glossary. Regen Med 2009:S1-S88.

6 Riazi AM, Kwon SY, Stanford WL: Stem cell sources for regenerative medicine. Methods Mol Biol 2009;482:55-90.
7 Sng J, Lufkin T: Emerging stem cell therapies: treatment, safety, and biology. Stem Cells Int 2012;2012:521343.

8 Weiss DJ, Kolls JK, Ortiz LA, PanoskaltsisMortari A, Prockop DJ: Stem cells and cell therapies in lung biology and lung diseases. Proc Am Thorac Soc 2008;5:637-667.

$\checkmark 9$ Tzouvelekis A, Antoniadis A, Bouros D: Stem cell therapy in pulmonary fibrosis. Curr Opin Pulm Med 2011;17:368-373.

-10 Anversa P, Perrella MA, Kourembanas S, Choi AM, Loscalzo J: Regenerative pulmonary medicine: potential and promise, pitfalls and challenges. Eur J Clin Invest 2012; 42:900-913.

11 Tzouvelekis A, Koliakos G, Ntolios P, et al: Stem cell therapy for idiopathic pulmonary fibrosis: a protocol proposal. J Transl Med 2011;9:182.
12 Lundin A, Driscoll B: Lung cancer stem cells: progress and prospects. Cancer Lett 2012, Epub ahead of print.

13 Lau AN, Goodwin M, Kim CF, Weiss DJ: Stem cells and regenerative medicine in lung biology and diseases. Mol Ther 2012;20: 1116-1130.

14 Sueblinvong V, Weiss DJ: Cell therapy approaches for lung diseases: current status. Curr Opin Pharmacol 2009;9:268-273.

15 Weiss DJ, Bertoncello I, Borok Z, Kim C, Panoskaltsis-Mortari A, Reynolds S, Rojas M, Stripp B, Warburton D, Prockop DJ: Stem cells and cell therapies in lung biology and lung diseases. Proc Am Thorac Soc 2011;8: 223-272. 